\section{CARACTERÍSTICAS AGRO- NÔMICAS E COMERCIAIS}

A cultivar Ramoso de Brasília é originalmente recomendada para plantios de inverno, podendo ser cultivada também em condições de verão ameno. $\mathrm{O}$ formato convexo da inflorescência permite o escoamento da água da chuva ou irrigação, tendo sido observada em campo uma redução acentuada de podridão-mole na inflorescência. O espaçamento recomendado para plantio é de $80 \times 50 \mathrm{~cm}$, um pouco mais adensado que o tradicionalmente utilizado para outras cultivares. Esse adensamento é possível devido ao menor porte das plantas da cultivar Ramoso de Brasília o que se traduz em maior produtividade por área. Durante o período de avaliação da cultivar em Brasília, obteve-se uma produtividade média de 18 t/ha, bastante significativa se comparada à produtividade alcançada, nas mesmas condições, com outras cultivares, inclusive híbridas, que variou entre 9 e 16 t/ha. Os demais tratos culturais são semelhantes àqueles normalmente utilizados para as demais cultivares.

Além das vantagens já mencionadas, observou-se ainda que a colheita de inflorescências na cultivar Ramoso de Brasília é bastante facilitada pelo comprimento longo das hastes, sendo feita muito mais rapidamente que nas demais cultivares. Além disso, os produtores que participaram da avaliação experimental da cultivar notaram que as inflorescências, uma vez atingido o ponto de colheita, mesmo que não sejam colhidas, permanecem com os botões florais fechados por mais tempo que as cultivares tradicionalmente utilizadas. Essa característica não compromete a qualidade das hastes e inflorescências, que permanecem tenras enquanto os botões florais estiverem fechados e permite maior flexibilidade na execução da colheita. Observou-se também que a cultivar Ramoso de Brasília apresenta inflorescências de melhor conservação pós-colheita, mantendo-se verdes, com aspecto de recém-colhidas, por um período mais longo.

\section{DISPONIBILIDADE DE SE- MENTES}

Quantidades maiores de sementes da cultivar Ramoso de Brasília podem ser adquiridas no comércio em geral, em boas casas de sementes ou produtos agropecuários. Pequenas quantidades, em amostras de até $3 \mathrm{~g}$, podem ser obtidas junto à Embrapa Hortaliças, mediante solicitação pessoal ou por carta, fax, telefone ou correio eletrônico.

BRUNE, S.; MELO, P.E. de; ÁVILA, A.C. de. Novos progenitores de batata imunes a PVY e PVX e resistentes à pinta-preta. Horticultura Brasileira, Brasília, v. 17, n. 2, p. 173-174, julho 1999.

\title{
Novos progenitores de batata imunes a PVY e PVX e resistentes à pinta-preta.
}

\author{
Sieglinde Brune; Paulo Eduardo de Melo; Antônio Carlos de Ávila. \\ Embrapa Hortaliças, C. Postal 218, 70.359-970 Brasília-DF. E.mail: linde@cnph.embrapa.br.
}

\section{RESUMO}

As viroses que ocorrem com muita frequência em plantas de batata no Brasil são responsáveis por queda na produtividade, principalmente quando provocados por uma combinação de vírus. Para PVY e PVX o tipo de resistência usada é a imunidade, controlada por genes simples e dominantes. A pinta-preta, causada pelo fungo Alternaria solani, é uma das principais doenças fúngicas da batata em condições de alta umidade e temperatura, podendo causar até $73 \%$ de perdas na produtividade. O uso da resistência genética é de grande interesse agronômico, uma vez que a eliminação ou redução do uso de agrotóxicos leva a menores custos de produção da lavoura, além de mitigar a poluição ambiental e os riscos ao ser humano. A Embrapa Hortaliças avalia anualmente, em seu programa de melhoramento da batata, a imunidade aos vírus PVY e PVX, a resistência à pinta-preta, além de observar as características agronômicas dos clones. Entre os genótipos avaliados em 1991 e 1992 destacaram-se os clones Embrapa/CIP-PP063 e Embrapa/CIP-PP084 com boas características agronômicas, imunidade a PVY e PVX e alto nível de resistência à pinta-preta. Ambos podem ser empregados como progenitores em programas de melhoramento que objetivem imunidade a esses vírus e resistência à pinta-preta. Os clones Embrapa/CIP-PP063 e o Embrapa/CIP-PP084 encontram-se à disposição de instituições interessadas em trabalhos cooperativos com a Embrapa Hortaliças, na forma de tubérculos ou plântulas in vitro.

Palavras-chave: Solanum tuberosum, Alternaria solani, germoplasma, fungo, melhoramento, PVY, PVX.

\section{ABSTRACT}

New potato progenitors immune to $\mathrm{PVY}$ and PVX, and resistant to early blight.

Viruses that occur frequently in potato crops in Brazil are responsible for crop yield losses, mainly when caused by a combination of viruses. For PVY and PVX the type of resistance used is immunity, controlled by single and dominant genes. Early blight caused by Alternaria solani is one of the most important potato diseases in Brazil, especially when high air humidity and warm weather conditions prevail. This disease can cause losses up to $73 \%$. The use of resistant varieties is an efficient control measure, being simultaneously harmless to environment and humans and providing an expressive reduction in costs. Genetic resistance has also the advantage that it can be used in association with other control methods in integrated disease management. In the potato breeding program, Embrapa Hortaliças annually evaluates the immunity to PVY and PVX, the resistance to early blight and agronomic traits. Among the clones evaluated in 1991 and 1992, 'Embrapa/CIP-PP063' and 'Embrapa/CIP-PP084' stood out with good agronomical characteristics, immunity to PVY and PVX, and high levels of resistance to early blight. Both are recommended for use as parents in breeding programs for resistance to early blight. Clones Embrapa/ CIP-PP063 and Embrapa/CIP-PP084 are available for cooperative work with other institutions, as in vitro plantlets or tubers.

Keywords: Solanum tuberosum, Alternaria solani, germplasm, fungus, breeding, PVY, PVX. 
$\mathrm{O}$ clone Embrapa/CIP-PP063 é resultado do cruzamento entre MAINE-28 e XY-9, realizado pelo Centro Internacional de la Papa (CIP), no Peru, em 1990. Testado na Embrapa Hortaliças em 1991, o clone Embrapa/ CIP-PP063 foi selecionado pela boa resistência à pinta-preta, igual à da cultivar Delta, mas inferior à da cultivar Aracy, utilizada como padrão de resistência. O clone Embrapa/CIP-PP063 apresentou, 60 dias após o plantio a nota 2,5 (12 a 25\% de área foliar infectada), contra a nota 3,4 da cultivar Bintje (25 a $50 \%$ ) e a nota 2,7 (12 a $25 \%)$ da cultivar Delta e 2,6 (12 a 25\%) da cultivar Aracy, quando cultivado na época chuvosa em Brasília. A resistência à pintapreta foi obtida através de notas atribuídas às plantas, de acordo com a área foliar infectada: notas de zero $(0 \%)$ a quatro $(50 \%)$ e nota cinco, correspondendo a plantas mortas. Como testemunhas de resistência conhecida foram utilizadas as cultivares Aracy, Delta e Bintje, resistente, de resistência intermediária e suscetível, respectivamente. Uma das características mais importantes do clone Embrapa/CIPPP063, além da resistência ao fungo, é a imunidade aos vírus PVX e PVY, causadores de mosaico e sabidamente responsáveis por redução significativa na produtividade da batata. Essa imunidade foi identificada no laboratório de virologia da Embrapa Hortaliças através de enxertia em plantas indicadoras, seguida de análise sorológica por ELISA. Além da resistência à pinta-preta e imunidade aos vírus, o clone Embrapa/CIPPP063 mostrou-se precoce, com ciclo vegetativo de 90 dias. As testemunhas Aracy, Delta e Bintje tiveram produtividades médias de 8,$4 ; 7,5$ e 8,5 t/ha de tubérculos comerciais respectivamente, contra 14 t/ha do clone Embrapa/CIPPP063, em segundo cultivo sem renovação dos tubérculos-sementes, durante a estação chuvosa em Brasília.

Os tubérculos do clone Embrapa/ CIP-PP063 apresentaram aspecto agronômico favorável, tendo formato oval e uniforme, película áspera e amarela, polpa amarela-clara e olhos rasos. Não foram encontrados defeitos fisiológicos nos tubérculos deste clone. O teor de matéria seca dos seus tubérculos foi de 20,3\%, enquanto a cultivar Bintje, nas mesmas condições de cultivo, apresentou tubér- culos com teor de matéria seca estimado em $18,3 \%$ (o teor de matéria seca foi estimado a partir do peso específico dos tubérculos, obtido pela razão entre peso no ar/peso na água de amostras de $1 \mathrm{~kg}$ ). Esses resultados, agregados ao tipo de tubérculo, permitem que este clone seja indicado para o processamento industrial na forma de palitos fritos. A utilização dos tubérculos para comercialização in natura pode apresentar alguma dificuldade devido à sua periderme áspera.

Os tubérculos foram avaliados ainda para tolerância ao esverdeamento. Para avaliar esta característica, os mesmos foram lavados e expostos à luz difusa durante 20 dias. As notas foram atribuídas em uma escala variando de 1 (ausência completa de esverdeamento) a 9 (esverdeamento muito forte). Os tubérculos do clone Embrapa/CIP-PP063 apresentaram alta tolerância ao esverdeamento, com nota 3,0 após 20 dias de exposição à luz. Nas mesmas condições, os tubérculos das cultivares Achat e Bintje apresentaram, respectivamente, notas 6,7 e 2,7 para esverdeamento.

Os brotos dos tubérculos do clone Embrapa/CIP-PP063, quando desenvolvidos sob luz difusa, apresentaram formato cônico, base azul-púrpura fortemente pigmentada e pouca pubescência. $\mathrm{O}$ ápice foi medianamente aberto e os brotos tiveram brotações laterais curtas e intensidade média de primórdios radiculares. As plantas formaram hastes vigorosas fortemente pigmentadas, com asas onduladas. Em Brasília foi observado bom florescimento e boa frutificação, havendo produção de pólen em abundância. As flores são brancas, de pedúnculo pigmentado.

Tubérculos ou plantas in vitro do clone Embrapa/CIP-PP063 encontramse à disposição de instituições interessadas em trabalhos cooperativos com a Embrapa Hortaliças.

O clone Embrapa/CIP-PP084 é resultado do cruzamento entre C-85.009 x XY13, realizado pelo Centro Internacional de la Papa (CIP), no Peru, em 1989. Testado na Embrapa Hortaliças em 1992, o clone Embrapa/CIP-PP084 foi selecionado pela boa resistência à pinta-preta, apresentando nota 2 (12\% de área foliar infectada) aos 60 dias após o plantio, quando cultivado na época chuvosa em Brasília. As cultivares Aracy, Delta e Bintje apresentaram nota de infeção 1,2 (2,5 a 12\%); 1,5
(2,5 a $12 \%)$ e 2,9 (12 a $25 \%)$ respectivamente. Este clone teve boa precocidade, com 85 dias de ciclo vegetativo. Ainda, apresenta a importante característica de ser imune aos vírus PVY e PVX, que em conjunto, têm ação bastante drástica sobre a produtividade da lavoura. O método utilizado para identificação de imunidade foi semelhante ao descrito para o clone Embrapa/CIP-PP063.

Os tubérculos apresentaram aspecto agronômico favorável, tendo formato redondo e uniforme, película áspera e amarela, polpa amarela-clara e olhos rasos. Não apresentaram defeitos fisiológicos. $\mathrm{O}$ teor de matéria seca estimada dos tubérculos foi de $20,3 \%$, enquanto a cultivar Bintje apresentou tubérculos com 21,7\% de matéria seca, nas mesmas condições de cultivo. Esse resultado indica a utilização deste clone para processamento na forma de fatias fritas. Uma vez que os tubérculos têm formato redondo, deve ser precedido de estudos de viabilidade, já que o teor de matéria seca observado foi comparativamente baixo. A sua utilização no mercado in natura não é indicada devido ao formato redondo dos tubérculos, de baixa aceitação pelo consumidor, além da sua película áspera.

Avaliado em sua capacidade de esverdeamento, em metodologia semelhante àquela descrita para o clone Embrapa/CIP-PP063, os tubérculos lavados após 20 dias de exposição à luz difusa, obtiveram nota 5,0 , podendo ser classificados como de tolerância intermediária ao esverdeamento. Como termo de comparação, tubérculos das cultivares Achat e Bintje obtiveram, no mesmo teste, nota 6,7 e 2,3 respectivamente.

Os brotos dos tubérculos, quando desenvolvidos sob luz difusa apresentaram formato oval, base verde e pouco pubescente. $\mathrm{O}$ ápice foi fechado e as brotações laterais curtas, com intensidade média de primórdios radiculares. As plantas são vigorosas, de hastes fortemente pigmentadas e asas retas. Em Brasília, o florescimento foi abundante, sendo as flores brancas e, externamente, levemente pigmentadas, com pedúnculo floral comprido. Houve boa produção de pólen e boa frutificação.

Esse clone, assim como o anterior, encontra-se à disposição de instituições interessadas em trabalhos cooperativos com a Embrapa Hortaliças, na forma de tubérculos ou como plântulas in vitro. 